Article

\title{
Fique as a Sustainable Material and Thermal Insulation for Buildings: Study of Its Decomposition and Thermal Conductivity
}

\author{
Gabriel Fernando García Sánchez ${ }^{1}\left(\mathbb{D}\right.$, Rolando Enrique Guzmán López ${ }^{2, *(\mathbb{D})}$ and Roberto Alonso Gonzalez-Lezcano ${ }^{3}$ (D) \\ 1 Grupo de Investigación en Energía y Medio Ambiente (GIEMA), School of Mechanical Engineering, \\ Universidad Industrial de Santander-UIS, Bucaramanga 680002, Colombia; g.garciasanchez@yahoo.es \\ 2 Grupo de Investigación en Desarrollo Tecnológico, Mecatrónica Y Agroindustria (GIDETECHMA), \\ Universidad Pontificia Bolivariana-UPB, Bucaramanga 680002, Colombia \\ 3 Architecture and Design Department, Escuela Politécnica Superior, Campus Montepríncipe, Universidad San \\ Pablo CEU, CEU Universities, Boadilla del Monte, 28668 Madrid, Spain; rgonzalezcano@ceu.es \\ * Correspondence: rolando.guzman@upb.edu.co
}

Citation: García Sánchez, G.F.; Guzmán López, R.E.;

Gonzalez-Lezcano, R.A. Fique as a Sustainable Material and Thermal Insulation for Buildings: Study of Its Decomposition and Thermal Conductivity. Sustainability 2021, 13, 7484. https://doi.org/10.3390/ su13137484

Academic Editor: Antonio Caggiano

Received: 11 June 2021

Accepted: 2 July 2021

Published: 5 July 2021

Publisher's Note: MDPI stays neutral with regard to jurisdictional claims in published maps and institutional affiliations.

Copyright: (c) 2021 by the authors. Licensee MDPI, Basel, Switzerland. This article is an open access article distributed under the terms and conditions of the Creative Commons Attribution (CC BY) license (https:// creativecommons.org/licenses/by/ $4.0 /)$.

\begin{abstract}
Buildings consume a large amount of energy during all stages of their life cycle. One of the most efficient ways to reduce their consumption is to use thermal insulation materials; however, these generally have negative effects on the environment and human health. Bio-insulations are presented as a good alternative solution to this problem, thus motivating the study of the properties of natural or recycled materials that could reduce energy consumption in buildings. Fique is a very important crop in Colombia. In order to contribute to our knowledge of the properties of its fibers as a thermal insulator, the measurement of its thermal conductivity is reported herein, employing equipment designed according to the ASTM C 177 standard and a kinetic study of its thermal decomposition from thermogravimetric data through the Coats-Redfern model-fitting method.
\end{abstract}

Keywords: thermal insulation; sustainable materials; fique; thermal conductivity; thermogravimetry; green architecture; thermogravimetry

\section{Introduction}

Global warming has become one of the greatest challenges facing humans in modern times, causing serious problems such as heat waves, drinking water shortages, and the spread of disease [1]. This phenomenon is mostly caused by the increase in the concentration of greenhouse gases in the atmosphere due to the use of fossil fuels to satisfy the growing demand for energy, which is, in turn, driven by population growth, the increase in the number of vehicles, and the development of new information technologies, among other reasons. According to the Intergovernmental Panel on Climate Change (IPCC), in each of the last three decades, the Earth's surface has been successively warmer than any previous decade since 1850 [2]. To alleviate this problem, it is necessary to develop new energy sources and to find ways to reduce society's energy consumption. The latter is a major challenge for the building sector, which, together with industry and transport, is one of the most energy-intensive sectors in the world, and is increasing due to the growing use of ventilation, air conditioning, and heating systems [3]. It is estimated that buildings consume about $40 \%$ of the world's energy, $25 \%$ of the world's water, and $40 \%$ of the world's resources, and are responsible for $1 / 3$ of the world's greenhouse gas emissions [4-6]. For this reason, there has been a great deal of interest in improving their energy efficiency around the world, which can be seen in the increase in research on the subject [7] and in the emergence of regulations [8,9].

The use of thermal insulation is recognized as one of the most efficient ways to reduce energy consumption in buildings [3,9-11]. For this purpose, materials obtained from petrochemical products (mainly polystyrene) or from processed natural sources with high energy consumption (such as rock wool and glass fiber) are often used. This has negative 
effects on the environment, both in terms of energy consumption and the generation of waste and emissions, mainly in the production stage [3,12], as well as causing serious problems for human health [13]. In fact, some of the materials used as insulation have recently been banned because they may pose health risks $[14,15]$. These problems could be addressed by using insulation made from recycled or natural materials (biomass) that do not require such a high degree of processing. Unfortunately, these materials are still in the development stage and, in many cases, their most important properties have not yet been fully determined [12]. The study of biomass as an insulating material (natural insulators) began in 1974 and remained a topic of little interest, with few scientific articles published until 1998, when the number of studies published on the subject began to increase. This trend progressed even more after 2003, and especially between 2010 and the present day. Currently, there is a great deal of interest in the development of this type of thermal insulator $[3,16-18]$. This interest is due to the increased environmental awareness of society, the increase in air conditioning systems-which require methods to reduce energy consumption - and changes in the use of biomass, for which other alternatives are required for its efficient use, as it is being replaced by hydrocarbon fuels in applications such as heating [3]. Studies on the subject have mainly been carried out in France, the UK, Italy, Turkey, and Algeria, which are the countries with neither the largest arable land area nor the largest number of forests; this can be explained by the greater environmental awareness of European countries compared with the rest of the world. Additionally, as expected, the most researched biomasses are from crops grown in these countries, i.e., hemp, straw, flax, wood, coconut, maize, and sunflower [3]. A comprehensive review of the state-of-the-art work on the main natural insulators around the world is presented in the works of Liu et al. [3], As-drubali et al. [12], Hurtado et al. [19], Mangesh et al. [20], Ingrao et al. [21], and Kymäläinen and Sjöberg [22].

The feasibility of using fique as a thermal insulating material is a subject that has rarely been studied in the world, which is evidenced by the low number of scientific articles published on the subject. However, there has been growing interest in the subject since 2003, which has been accentuated since 2010. Some of the most relevant works on the subject are presented in Table 1. The superficial characteristics of fique fibers were studied by Guzmán et al. [23]. An expansion in the field of research towards the manufacture of composite materials (biopolymer/fiber, aerogel/fiber) is shown in the works of An et al. [24] and Dou et al. [25]. Fique is a crop of great importance for Colombia, which is the world's main producer, and the livelihoods of more than 70,000 Colombian families depend on its production [26]. In the country, the plant's fibers are widely available throughout the year [27], making it ideal for uses beyond the manufacture of ropes and garments in order to contribute to our knowledge of the properties of fique as a thermal insulator and provide a more holistic overview of the environmental impact during the whole specific life cycle phase [28,29], from raw material extraction to end of life stages; hence enabling justified decisions on the suitability of using fique fibers in thermal insulation [30]. This paper reports the measurement of its thermal conductivity, by means of the guarded hot plate method (ASTM C 177), and a study of its thermal decomposition by means of the analysis of thermogravimetric data using the Coats-Redfern method. 
Table 1. Studies on the characterization of fique as a thermal insulator.

\begin{tabular}{|c|c|c|}
\hline Authors & Description & Year \\
\hline Muñoz y Cifuentes [31] & $\begin{array}{l}\text { Study of the thermal life of containers insulated with fique and the thermal } \\
\text { conductivity of four commercial presentations of the material (chopped, } \\
\text { unchopped, in wadding fabric and chopped in a thermosetting resin matrix). }\end{array}$ & 2007 \\
\hline Onésippe et al. [32] & $\begin{array}{l}\text { Analysis of the mechanical and thermal behavior of a composite material made of } \\
\text { cement reinforced with bagasse and fique fibers. }\end{array}$ & 2008 \\
\hline Monsalve et al. [33] & $\begin{array}{l}\text { Study of the mechanical and thermal behavior of a material made up of three } \\
\text { layers: two outer layers of composite with cementitious matrix with fique fiber and } \\
\text { aluminum oxide powder and an inner layer of recycled newsprint pulp (cellulose). }\end{array}$ & 2013 \\
\hline Navacerrada et al. [34] & $\begin{array}{l}\text { Characterization of samples made of woven and nonwoven fique of different } \\
\text { densities and thicknesses, for which sound absorption, air flow resistivity, and } \\
\text { thermal conductivity as a function of density were measured. }\end{array}$ & 2013 \\
\hline Navacerrada et al. [35] & $\begin{array}{l}\text { Characterization of samples made up of nonwoven fique samples with a } \\
\text { polymeric surface coating. }\end{array}$ & 2014 \\
\hline Proaño [36] & $\begin{array}{l}\text { Development of two types of rigid polyurethane matrix composite materials, one } \\
\text { reinforced with cabuya (fique) fibers and the other reinforced with African palm } \\
\text { rachis fibers. Tests were carried out on bending, traction, density, combustion } \\
\text { speed, and acoustic and thermal properties. }\end{array}$ & 2015 \\
\hline Navacerrada et al. [37] & $\begin{array}{l}\text { Determination of the acoustic and thermal properties of samples made from } \\
\text { coconut, coconut/fique, and fique nonwoven fibers, which were produced by two } \\
\text { methods: pressing with binder and punching. }\end{array}$ & 2016 \\
\hline Vera [38] & $\begin{array}{c}\text { Study of the acoustic and thermal performance of cabuya fiber as a wall } \\
\text { cladding panel. }\end{array}$ & 2018 \\
\hline García et al. [39] & $\begin{array}{l}\text { Morphological study and description of the thermal decomposition process of } \\
\text { three types of fique fiber samples: untreated, washed with a commercial softener, } \\
\text { and after soaking for } 24 \mathrm{~h} \text { in the same softener. }\end{array}$ & 2019 \\
\hline Gómez et al. [40] & $\begin{array}{l}\text { Morphological and thermo-acoustic characterization of nonwoven fique samples. } \\
\text { The sound absorption, resistivity, dynamic stiffness and thermal conductivity of } \\
\text { the material were measured. }\end{array}$ & 2020 \\
\hline
\end{tabular}

\section{Methodology}

\subsection{Measurement of Thermal Conductivity}

Thermal conductivity is one of the main characteristics of thermal insulators. According to standards such as TS 825, ISO 9164:1989 and DIN 4108, materials with thermal conductivities of less than $0.07 \mathrm{~W} / \mathrm{m} \cdot \mathrm{K}$ can be considered thermal insulators [41]; other studies consider materials to be thermal insulators if the conductivity is less than $0.1 \mathrm{~W} / \mathrm{m} \cdot \mathrm{K}$ [14] One of the most widely used methods to measure this property is the protected hot plate method, which consists of taking the sample to a stationary state with two different and known temperatures so that Fourier's law of heat conduction in its one-dimensional form is applicable; this can be expressed as follows:

$$
k=\frac{\dot{Q} L}{A \Delta T}
$$

where $k$ is the thermal conductivity of the material, $Q$ is the heat transfer rate, $L$ is the thickness of the sample, $A$ is the heat transfer area, and $\Delta T$ is the temperature difference. For this purpose, the sample is located between two plates that act as a heat source and a heat sink, in order that, from their temperatures, the power required by the device, its geometry, and the material's ability to conduct heat can be calculated.

In the present study, the protected hot plate method was used to measure the conductivity of nonwoven fique samples at different densities, for which the equipment shown in Figure 1 was built, which was designed according to ASTM C 177-13 [42] with a double- 
sided configuration to ensure a stable and constant transmission of energy by conduction perpendicular to the surfaces of the samples. This device consists of four main parts, namely: a measurement and control system, a support system, a heating system, and a cooling system, which are presented in Figure 1.

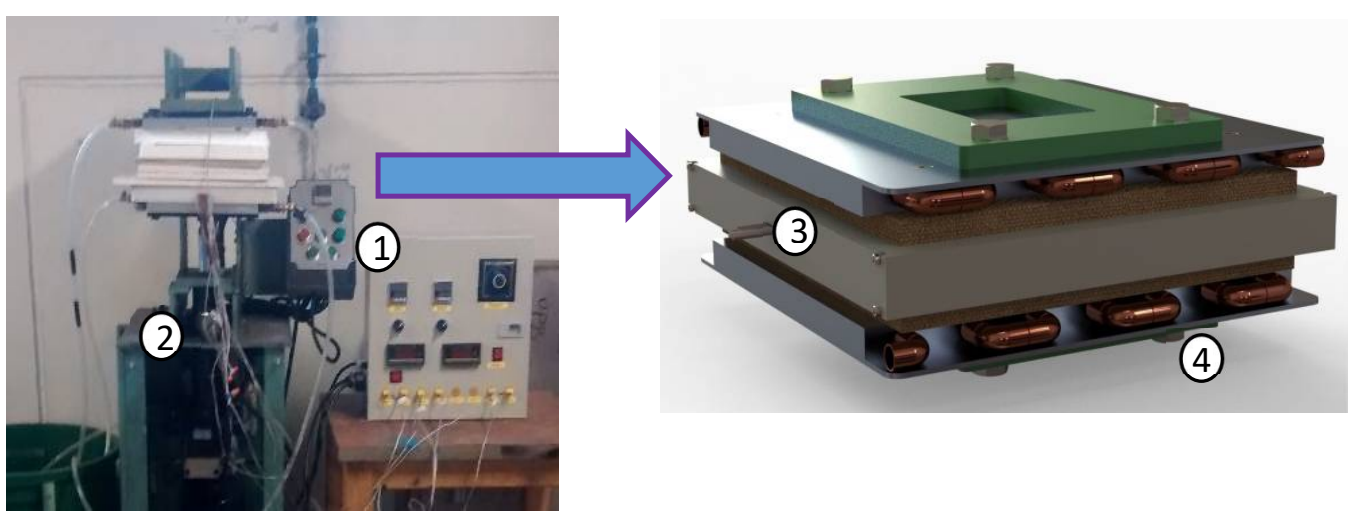

Figure 1. Thermal conductivity measuring bench in accordance with ASTM C 177-13. (1) Measuring and control system, (2) support system, (3) heating system, and (4) cooling system.

\subsubsection{Measurement and Control System}

The measurement and control system allows real-time temperature measurement by means of eight K-type thermocouples, four located on the hot plate (Figure 2b) and four on the cold plates (two on the upper plate and two on the inner plate). The system also supplies the electrical power required by the two flat plate heaters, which are controlled by two electronic PID microcontrollers (Autonics TCN4).

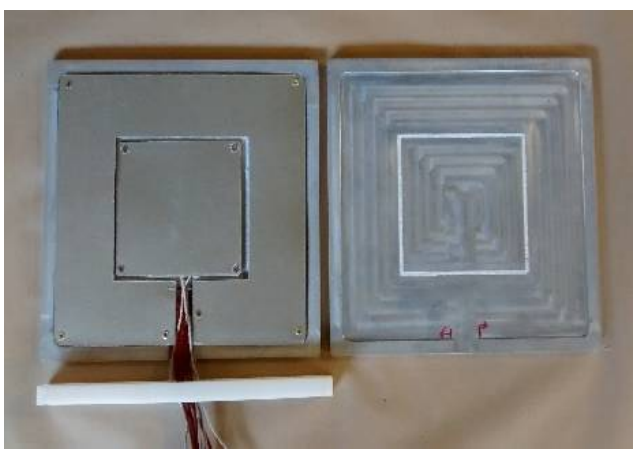

(a)

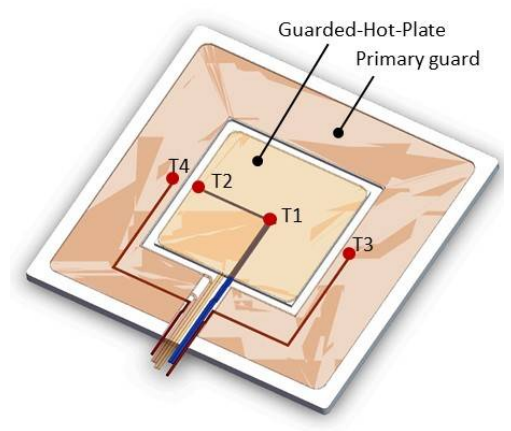

(b)

Figure 2. Heating system: (a) aluminum plates and electrical resistors and (b) thermocouples for temperature measurement in the system.

\subsubsection{Support System}

The support system supports the other systems and is mounted on a hydraulic unit, which ensures constant pressure on the specimens by means of a hydraulic actuator, thus ensuring the reproducibility of the measurements.

\subsubsection{Heating System (Guarded-Hot-Plate)}

The heating system consists of two aluminum plates, measuring $300 \mathrm{~mm} \times 300 \mathrm{~mm} \times$ $10 \mathrm{~mm}$, in the middle of which there are two independent flat coplanar resistors, as shown in Figure 2; one corresponding to the area of the protected hot plate with a power value of $225 \mathrm{~W}(150 \mathrm{~mm} \times 150 \mathrm{~mm})$ and another resistor corresponding to the area of the primary guard, which supplies an electrical power of $360 \mathrm{~W}$. Four temperature sensors (T1, T2, T3, 
T4) are located on the plate to measure the temperature values and to ensure that there is no lateral flow, i.e., that there is only unidirectional flow.

\subsubsection{Cooling System}

The cooling system consists of two aluminum plates (cold surfaces), measuring $300 \mathrm{~mm} \times 300 \mathrm{~mm} \times 20 \mathrm{~mm}$, through which seven $\frac{1}{2}$-inch copper tubes pass on each plate, as shown in Figure 3. Two K-type thermocouples (T5-T8) are placed on each cold plate to obtain temperature data during the test.

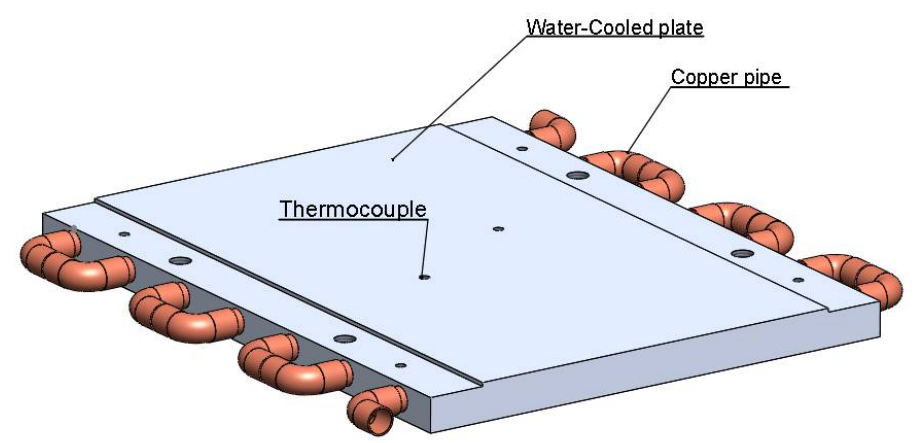

Figure 3. Cooling system assembly with two heat exchangers.

\subsection{Kinetic Modelling}

Kinetics, represented by the kinetic triplet, is an important property for the study of the thermal decomposition of biomass, as it allows the complete simulation of the conversion vs. time curve, as well as the control and optimization of the process parameters. The most common method to determine it is the analysis of thermogravimetric (TG) data [43,44], as it is the most effective, least expensive, and simplest way to observe fuel combustion and pyrolysis profiles [45]. The thermogravimetric (TG) tests were carried out in a TGA Q500-TA instruments analyzer, using a nitrogen atmosphere with a constant flow rate of $15 \mathrm{~mL} / \mathrm{min}$ and a heating rate of $5^{\circ} \mathrm{C} / \mathrm{min}$, taking the sample from $27^{\circ} \mathrm{C}$ to $480^{\circ} \mathrm{C}$.

The rate at which the thermal decomposition process of solid samples occurs is usually expressed by Equation (2):

$$
\frac{d \alpha}{d t}=f(\alpha) A \exp \left(-\frac{E_{a}}{R_{u} T}\right)
$$

where $f(\alpha)$ is known as the decomposition function or reaction model, $A$ is the preexponential factor, $E a$ the activation energy, Ru the universal pass constant, and $T$ the absolute temperature. This equation has no analytical solution, so several methods have been developed to determine the factors $f(\alpha), E a$, and $A$ (known as the kinetic triplet), which can be classified into fitting and isoconversional models. In the former, a predefined form of $f(\alpha)$ is assumed, while, in the latter, data with the same value as the degree of conversion $\alpha$ are selected, so that $f(\alpha)$ is constant, and $A$ and $E a$ are independent of its form, allowing the Arrhenius equation to be evaluated without choosing the order of the reaction. Fitting methods have been widely used in solid-state reactions due to their ability to directly determine the kinetic parameters from TG data at a single heating rate, one of the most important of which is the Coats-Redfern integral method [46], which has been successfully used in the kinetic modelling of plant biomass, as can be seen in the work of Alvarez et al. [47] According to this method, Equation (2) has the following solution:

$$
\ln \left(\frac{g(\alpha)}{T^{2}}\right)=\ln \left[\frac{A R_{u}}{\beta E_{a}}\left(1-\frac{2 R_{u} T}{E_{a}}\right)\right]-\frac{E_{a}}{R_{u} T}
$$


where $g(\alpha)$ is the integral form of the reaction model and $\beta$ is the reaction rate. The $2 R u T / E a$ term is very small, so it is usually neglected, leading to:

$$
\ln \left(\frac{g(\alpha)}{T^{2}}\right)=\ln \left[\frac{A R_{u}}{\beta E_{a}}\right]-\frac{E_{a}}{R_{u} T}
$$

Thus, the graph $\ln \left(\frac{g(\alpha)}{T^{2}}\right)$ vs. $\frac{1}{T}$ is a straight line with slope $-E a / R u$ and ordinate at the origin equal to $\ln \left[\frac{A R_{u}}{\beta E_{a}}\right]$, which allows us to clear the values of $E a$ and $A$. To determine the reaction model, the "master plots" graphs were used, which is the method recommended by the International Confederation for Thermal Analysis and Calorimetry (ICTAC) [48,49]. For this purpose, the reaction models presented in Table 2 were plotted first, and then the experimental curve $g(\alpha) / g(0.5)$ vs. $\alpha$ was plotted and the theoretical curve that best fit according to equality was chosen:

$$
\frac{g(\alpha)}{g(0.5)}=\frac{\frac{E_{a} A}{\beta R} p(x)}{\frac{E_{a} A}{\beta R} p\left(x_{0.5}\right)}=\frac{p(x)}{p\left(x_{0.5}\right)}
$$

where $x=E a / R T, p(x)$ is calculated according to the approximation of Pérez-Maqueda and Criado [50]:

$$
p(x)=\left(\frac{e^{-x}}{x}\right)\left(\frac{x^{7}+70 x^{6}+1886 x^{5}+24,920 x^{4}+170,136 x^{3}+577,584 x^{2}+844,560 x+35,120}{x^{8}+72 x^{7}+2024 x^{6}+28,560 x^{5}+216,720 x^{4}+880,320 x^{3}+1,794,240 x^{2}+1,572,480 x+403,200}\right)
$$

The experimental conversion data were compared with the respective theoretical ones obtained from kinetic modelling, and the quality of their fit was evaluated by means of the average percentage deviation (AVP) proposed by Orfao et al. [51]:

$$
\begin{gathered}
A V P=100 \sqrt{\frac{S S}{N}} \\
S S=\sum_{i=0}^{N}\left[(\alpha)_{i, \exp }-(\alpha)_{i, t e o}\right]^{2}
\end{gathered}
$$

where $\alpha \exp$ is the experimental conversion and $\alpha$ teo is the theoretical conversion, deter-

\begin{tabular}{|c|c|c|c|}
\hline Reaction Model & Code & $f(\alpha)^{a}$ & $g(\alpha)^{b}$ \\
\hline Power law & P1 & $4 \alpha^{3 / 4}$ & $\alpha^{1 / 4}$ \\
\hline Power law & P2 & $3 \alpha^{2 / 3}$ & $\alpha^{1 / 3}$ \\
\hline Power law & P3 & $2 \alpha^{1 / 2}$ & $\alpha^{1 / 2}$ \\
\hline Power law & $\mathrm{P} 4$ & $2 / 3 \alpha^{1 / 2}$ & $\alpha^{3 / 2}$ \\
\hline $\begin{array}{l}\text { Phase-boundary controlled reaction } \\
\text { (contracting area) }\end{array}$ & $\mathrm{R} 2$ & $2(1-\alpha)^{1 / 2}$ & {$\left[1-(1-\alpha)^{1 / 2}\right]$} \\
\hline $\begin{array}{l}\text { Phase-boundary controlled reaction } \\
\text { (contracting volume) }\end{array}$ & R3 & $3(1-\alpha)^{2 / 3}$ & {$\left[1-(1-\alpha)^{1 / 3}\right]$} \\
\hline Avrami Erofe'ev $(\mathrm{m}=2)$ & A2 & $2(1-\alpha)[-\ln (1-\alpha)]^{1 / 2}$ & {$[-\ln (1-\alpha)]^{1 / 2}$} \\
\hline Avrami Erofe'ev $(\mathrm{m}=3)$ & A3 & $3(1-\alpha)[-\ln (1-\alpha)]^{2 / 3}$ & {$[-\ln (1-\alpha)]^{1 / 3}$} \\
\hline Avrami Erofe'ev $(\mathrm{m}=4)$ & A4 & $4(1-\alpha)[-\ln (1-\alpha)]^{3 / 4}$ & {$[-\ln (1-\alpha)]^{1 / 4}$} \\
\hline First-order & $\mathrm{F} 1$ & $(1-\alpha)$ & $-\ln (1-\alpha)$ \\
\hline$n$ th-order & Fn & $(1-\alpha)^{n}$ & $\underline{\left[1-(1-\alpha)^{1-n}\right]}$ \\
\hline One-dimensional diffusion & D1 & $\frac{1}{2 \alpha}$ & $\begin{array}{l}1-n \\
\alpha^{2}\end{array}$ \\
\hline
\end{tabular}
mined from Equation (2) and the kinetic triplet calculated from the reaction models, and $N$ is the number of experimental TG data.

Table 2. Integral ${ }^{a}$ and differential ${ }^{b}$ form of various reaction models for solid phase kinetics. Information taken from Rueda-Ordoñez [52]. 
Table 2. Cont.

\begin{tabular}{|c|c|c|c|}
\hline Reaction Model & Code & $f(\alpha)^{a}$ & $g(\alpha)^{b}$ \\
\hline Two-dimensional diffusion & D2 & {$[-\ln (1-\alpha)]^{-1}$} & $(1-\alpha) \ln (1-\alpha)+\alpha$ \\
\hline Three-dimensional diffusion & D3 & $\left(\frac{3}{2}\right)(1-\alpha)^{2 / 3}\left[1-(1-\alpha)^{1 / 3}\right]^{-1}$ & {$\left[1-(1-\alpha)^{1 / 3}\right]^{2}$} \\
\hline Ginstling-Brounstein diffusion & D4 & $\left(\frac{3}{2}\right)\left[(1-\alpha)^{1 / 3}-1\right]^{-1}$ & $\left(1-\frac{2 \alpha}{3}\right)-(1-\alpha)^{2 / 3}$ \\
\hline
\end{tabular}

\section{Results and Discussion}

\subsection{Thermal Conduction}

Figure 4 shows the influence of the density of the fique samples on their thermal conductivity. Density was one of the manufacturing parameters controlled during the elaboration of the samples, obtaining three levels of density: $50 \mathrm{~kg} / \mathrm{m}^{3}, 65 \mathrm{~kg} / \mathrm{m}^{3}$, and $80 \mathrm{~kg} / \mathrm{m}^{3}$. As can be seen, there is a small decrease in thermal conductivity with increasing density in the 50 to $80 \mathrm{~kg} / \mathrm{m}^{3}$ range, where the maximum average value is $0.06 \mathrm{~W} / \mathrm{m} \cdot \mathrm{K}$ at a density of $50 \mathrm{~kg} / \mathrm{m}^{3}$, while the minimum average value is $0.055 \mathrm{~W} / \mathrm{m} \cdot \mathrm{K}$ at $80 \mathrm{~kg} / \mathrm{m}^{3}$. It seems reasonable to expect an increase in thermal conductivity with the increasing density of the nonwovens, as the solid fraction increases. However, the sample of fique nonwovens with the highest density has the lowest thermal conductivity value. This indicates that voids are also a parameter to be considered, as the results suggest that the higher the packing density, the smaller the size of the voids and the higher the thermal resistance.

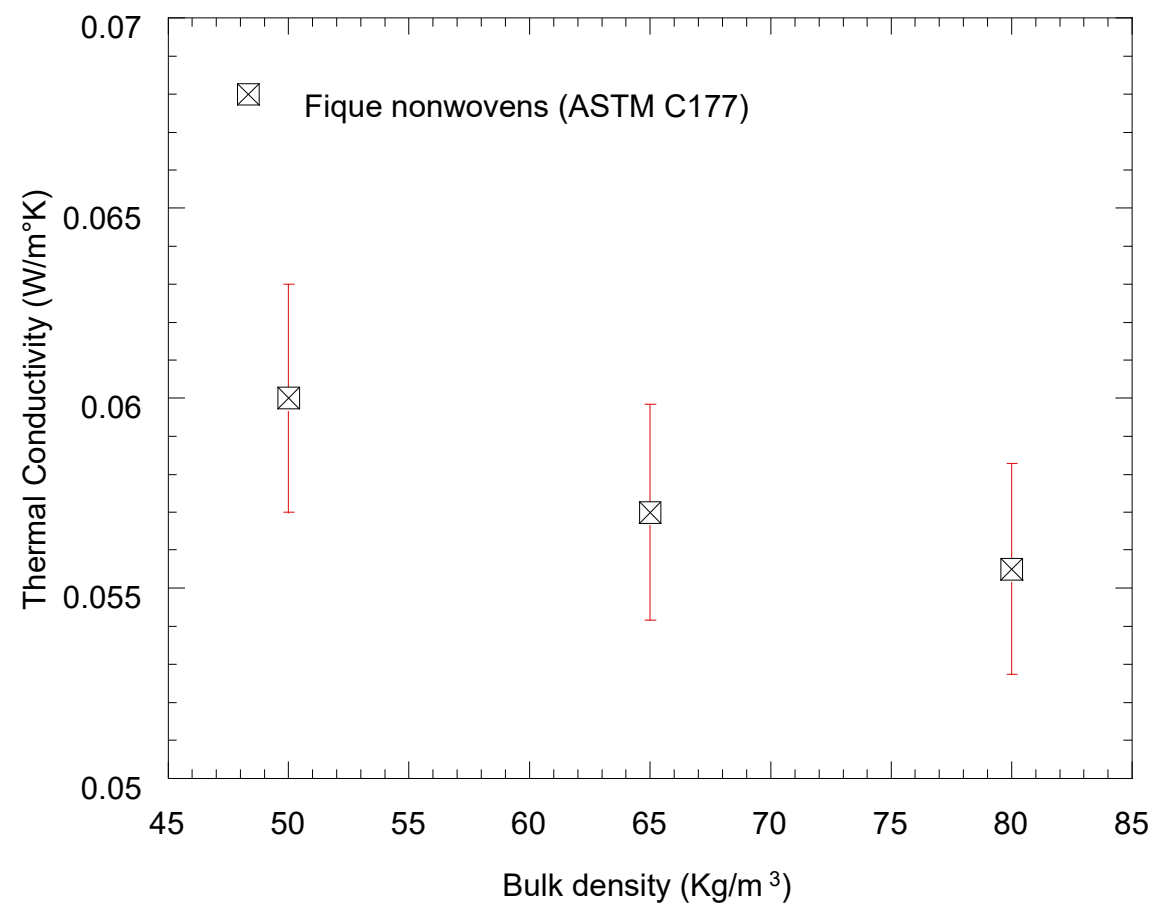

Figure 4. Results of thermal conductivity measurements at different densities.

\subsection{Thermal Decomposition}

Figure 5 shows the TG-DTG profile of the analyzed sample. As can be seen, there are five stages: a first stage of weight loss due to drying, a stable phase with no weight loss, two stages of high loss due to the decomposition process, and a final stage of degradation and combustion. It has been observed that hemicellulose, cellulose, and lignin decompose from 197 to $327^{\circ} \mathrm{C}, 277$ to $427^{\circ} \mathrm{C}$, and 277 to $527^{\circ} \mathrm{C}$, respectively [53]; therefore, the third stage can be attributed to the decomposition of hemicellulose and cellulose, while the fourth stage can be attributed to the decomposition of cellulose and lignin. 


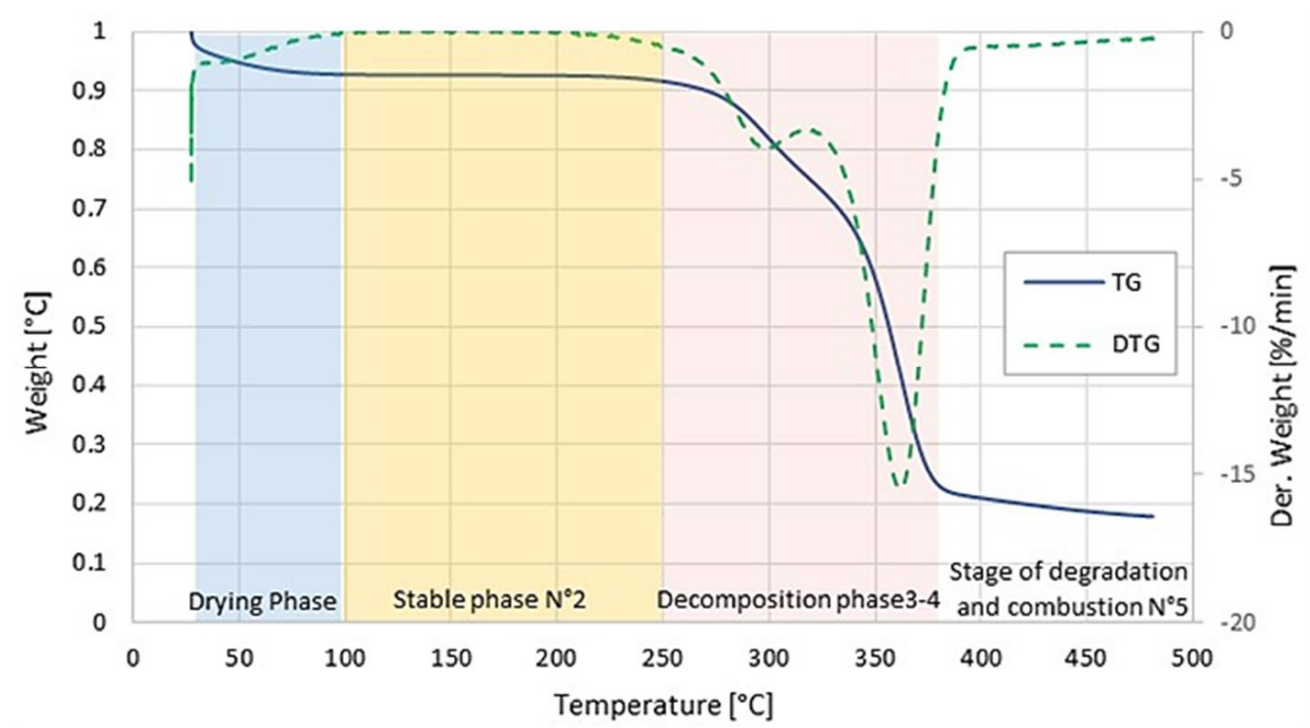

Figure 5. TG-DTG diagram of the fique samples.

Applying the Coats-Redfern method to the data obtained from the thermogravimetric tests, we obtained the straight $\operatorname{line} \ln \left(\frac{g(\alpha)}{T^{2}}\right)$ vs. $\frac{1}{T}$ presented in Figure 6a. The correlation coefficient (R2) of this plot is 0.9903 , which speaks well for the efficiency of the method. The values of the activation energy and pre-exponential factor obtained from this graph were $120.12 \mathrm{~kJ} / \mathrm{mol}$ and $2.62 \times 10^{7}$. On the other hand, by applying the "Master Plots" method, it was found that the reaction model that best fit the analyzed biomass was the "Power law-P4", as presented in Figure 6b.

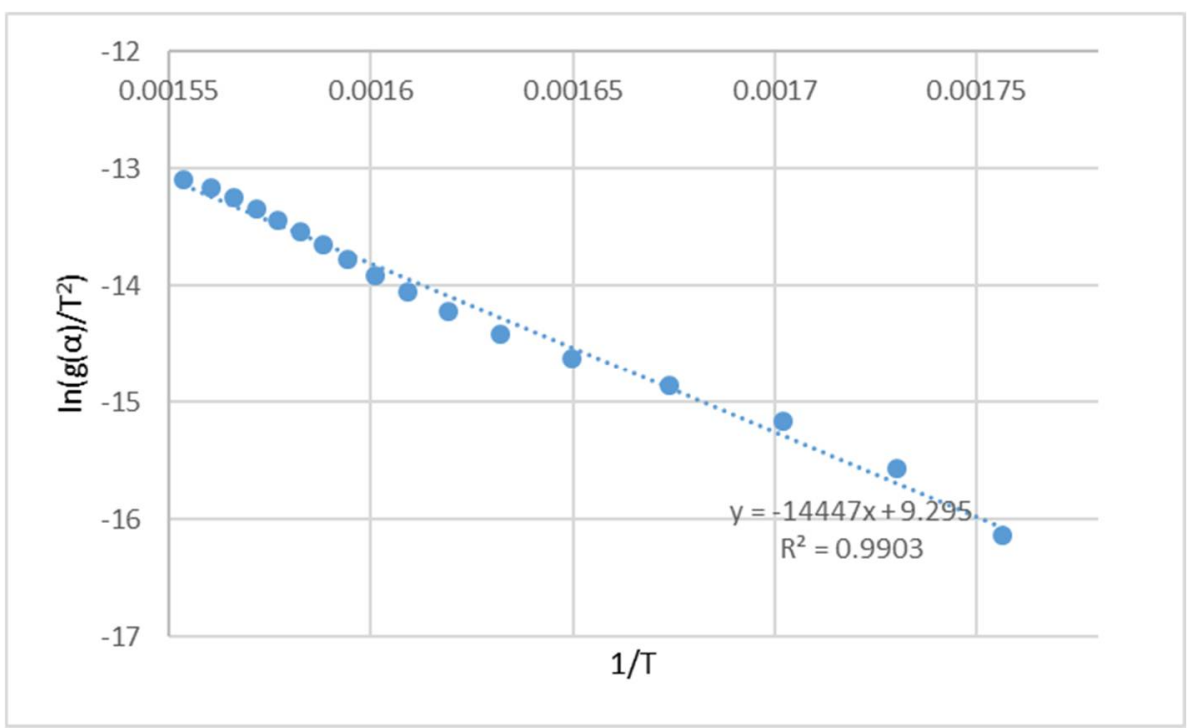

(a)

Figure 6. Cont. 


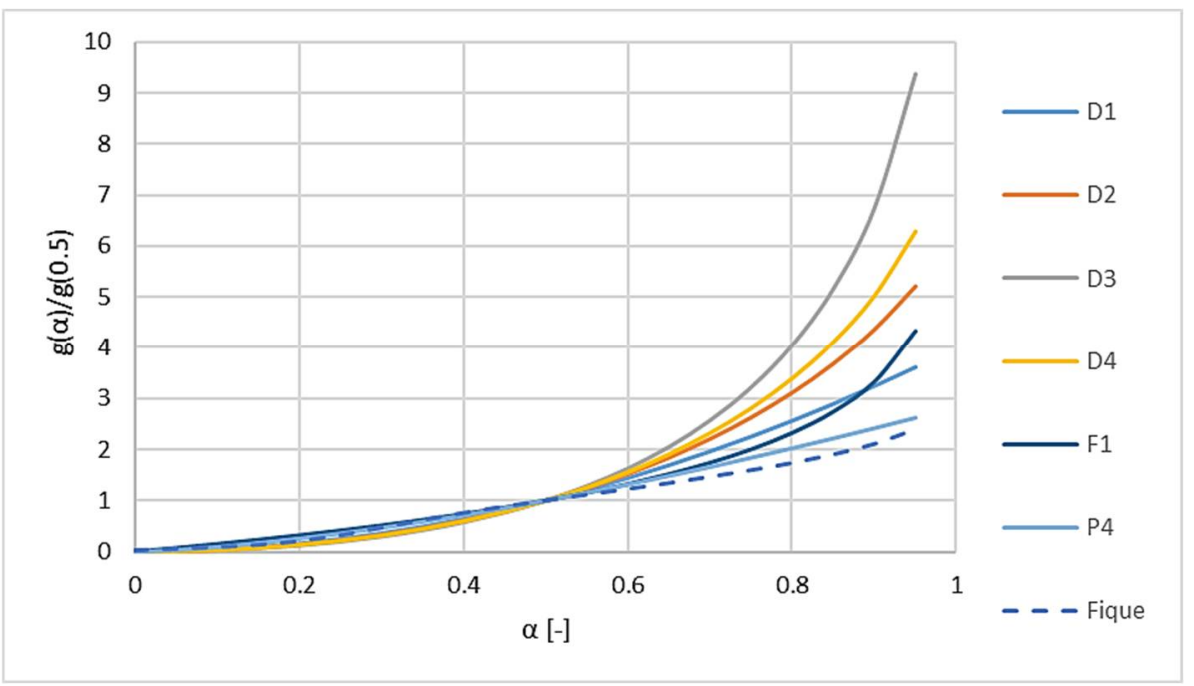

(b)

Figure 6. Determination of the kinetic triplet: (a) activation energy and pre-exponential factor by the Coats-Redfern method and (b) reaction model by means of the "Master Plots" method.

The results obtained show that, as expected, fique fibers decompose much faster than common insulators, so it is necessary to apply treatments or mix them with other materials to improve their resistance to high temperatures. The evaluation of the results by comparing the theoretical and experimental conversion curves is presented in Figure 7 . As can be seen at the beginning and end of the process, there is a small underestimation of the results when using the model; however, the difference is very small, so a good fit is observed. To evaluate this adjustment, the average deviation percentage (AVP) was calculated, which gave a result of $3.7 \%$, indicating that the results obtained can be used successfully in the simulation of the thermal decomposition of fique fibers.

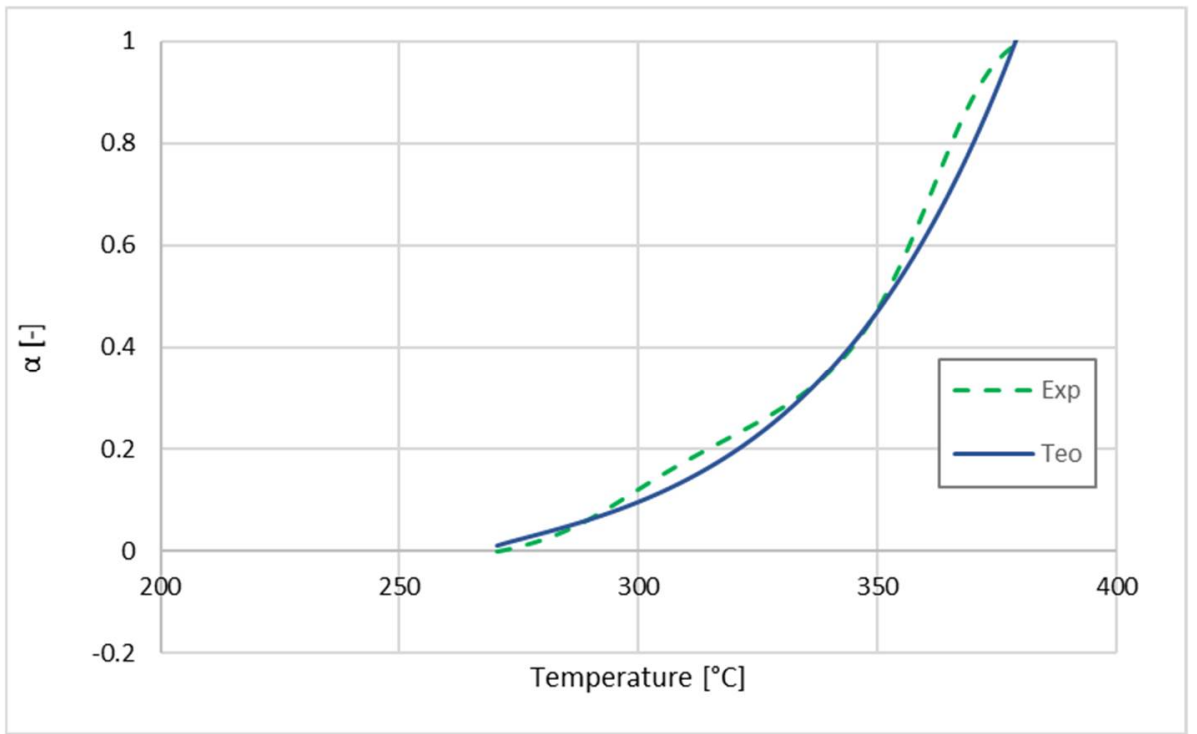

Figure 7. Theoretical and experimental conversion curves.

\section{Conclusions}

Equipment for measuring thermal conductivity was built, based on the ASTM C 177-13 standard, with which samples of nonwoven fique fibers of densities between 50 and $80 \mathrm{~kg} / \mathrm{m}^{3}$ were tested. The conductivity of the samples was found to be between 0.055 and $0.06 \mathrm{~W} / \mathrm{m} \cdot \mathrm{K}$, which is a value close to that of the common insulators found on the market. 
This indicates that, from a heat transfer point of view, the material can be a good thermal insulator for buildings.

Thermogravimetric tests were also carried out in an inert atmosphere at $10^{\circ} \mathrm{C} / \mathrm{min}$ on the fique samples. It was observed that the thermal decomposition process consists of five stages: drying, heating without loss of mass, two stages of decomposition, and final degradation. These were carried out in the temperature ranges: $27-100{ }^{\circ} \mathrm{C}, 100-250{ }^{\circ} \mathrm{C}$, $250-320^{\circ} \mathrm{C}, 320-378{ }^{\circ} \mathrm{C}$, and $378-480^{\circ} \mathrm{C}$, respectively.

From the TG data, the kinetic modelling of the biomass was carried out by means of the Coats-Redfern method, using the master plot curves for the determination of the reaction models, thus obtaining the kinetic triplet that allows us to model its thermal decomposition process. The results obtained were evaluated by comparing the theoretical and experimental conversion curves, obtaining average deviation percentages (AVP) of less than $4 \%$, which leads us to the conclusion that the value of the kinetic triplet obtained is adequate for modelling the thermal decomposition process.

Very few studies evaluate the environmental impacts "cradle to grave" in a rigorous way, using, for instance, the life cycle assessment approach (LCA) of nonwoven fique samples. This lack of data is mainly caused by the state of the research on these materials that is still at an early stage. Further analyses should also be performed to evaluate other important properties for thermal insulators such as fire classification, resistance to water vapor diffusion, acoustic absorption, degradation due to moisture, bacteria, mildew, and fungi. In conclusion, issues remain to be solved before the widespread use of the fique nonwoven materials as thermal insulators.

Author Contributions: Conceptualization, G.F.G.S. and R.E.G.L.; methodology, G.F.G.S. and R.E.G.L.; validation, G.F.G.S., R.E.G.L. and R.A.G.-L.; resources, G.F.G.S., R.E.G.L. and R.A.G.-L.; review and editing G.F.G.S., R.E.G.L. and R.A.G.-L. All authors have read and agreed to the published version of the manuscript.

Funding: The authors wish to thank CEU San Pablo University Foundation for the funds dedicated to the Project Ref. USP CEU-CP20V12 provided by CEU San Pablo University.

Institutional Review Board Statement: Not applicable.

Informed Consent Statement: Not applicable.

Data Availability Statement: Not applicable.

Acknowledgments: Funding from Minciencias, Ministry of National Education, Ministry of Industry, Commerce and Tourism and ICETEX, Scientific Ecosystem-Colombia Científica, Fund Francisco José de Caldas, through Contract RC-FP44842-212-2018, is gratefully acknowledged and the Universidad Pontificia Bolivariana under grant No. 028-0717-2600.

Conflicts of Interest: The authors declare no conflict of interest.

\section{References}

1. Ortiz, A.C.; Peña, J.Z. Implicaciones Históricas y Biológicas del Cambio Climático. NOVA 2010, 8. Available online: http: //unicolmayor.edu.co/publicaciones/index.php/nova/article/view/154 (accessed on 8 October 2015).

2. IPCC - Intergovernmental Panel on Climate Change. Cambio Climático 2014-Impactos, Adaptación y Vulnerabilidad. Available online: http:/ / www.ipcc.ch/home_languages_main_spanish.shtml (accessed on 24 October 2016).

3. Liu, L.; Li, H.; Lazzaretto, A.; Manente, G.; Tong, C.; Liu, Q.; Li, N. The development history and prospects of biomass-based insulation materials for buildings. Renew. Sustain. Energy Rev. 2017, 69, 912-932. [CrossRef]

4. United Nations Environment Programme (UNEP)—SBCI. Available online: http://www.unep.org/sbci/AboutSBCI/Background. asp (accessed on 19 October 2016).

5. Buildings Energy Data Book. Available online: http://buildingsdatabook.eren.doe.gov/ChapterIntro1.aspx (accessed on 19 October 2016).

6. Buildings-Energy-European Commission. Energy. Available online: http://ec.europa.eu/energy/en/topics/energyefficiency/buildings (accessed on 19 October 2016).

7. De Boeck, L.; Verbeke, S.; Audenaert, A.; De Mesmaeker, L. Improving the energy performance of residential buildings: A literature review. Renew. Sustain. Energy Rev. 2015, 52, 960-975. [CrossRef] 
8. Carpio, C.; Coviello, M. Eficiencia Energética en América Latina y el Caribe: Avances y Desafíos del último Quinquenio. Available online: http:/ / www.cepal.org/es/publicaciones/4106-eficiencia-energetica-america-latina-caribe-avances-desafios-ultimoquinquenio (accessed on 19 October 2016).

9. Schiavoni, S.; D'Alessandro, F.; Bianchi, F.; Asdrubali, F. Insulation materials for the building sector: A review and comparative analysis. Renew. Sustain. Energy Rev. 2016, 62, 988-1011. [CrossRef]

10. Tangjuank, S. Thermal insulation and physical properties of particleboards from pineapple leaves. Int. J. Phys. Sci. 2011, 6, 4528-4532.

11. Papadopoulos, A. State of the art in thermal insulation materials and aims for future developments. Energy Build. 2005, 37, 77-86. [CrossRef]

12. Asdrubali, F.; D'Alessandro, F.; Schiavoni, S. A review of unconventional sustainable building insulation materials. Sustain. Mater. Technol. 2015, 4, 1-17. [CrossRef]

13. Binici, H.; Aksogan, O.; Demirhan, C. Mechanical, thermal and acoustical characterizations of an insulation composite made of bio-based materials. Sustain. Cities Soc. 2016, 20, 17-26. [CrossRef]

14. Mati-Baouche, N.; De Baynast, H.; Lebert, A.; Sun, S.; Lopez-Mingo, C.J.S.; Leclaire, P.; Michaud, P. Mechanical, thermal and acoustical characterizations of an insulating bio-based composite made from sunflower stalks particles and chitosan. Ind. Crops Prod. 2014, 58, 244-250. [CrossRef]

15. Mounika, M.; Ramaniah, K.; Prasad, A.R.R.; Rao, K.M.; Reddy, K. Thermal conductivity characterization of bamboo fiber reinforced polyester composite. J. Mater. Environ. Sci. 2012, 3, 1109-1116.

16. Binici, H.; Eken, M.; Dolaz, M.; Aksogan, O.; Kara, M. An environmentally friendly thermal insulation material from sunflower stalk, textile waste and stubble fibres. Constr. Build. Mater. 2014, 51, 24-33. [CrossRef]

17. Pinto, J.; Paiva, A.; Varum, H.; Costa, A.; Cruz, D.; Pereira, S.; Fernandes, L.; Tavares, P.; Agarwal, J. Corn's cob as a potential ecological thermal insulation material. Energy Build. 2011, 43, 1985-1990. [CrossRef]

18. Wei, K.; Lv, C.; Chen, M.; Zhou, X.; Dai, Z.; Shen, D. Development and performance evaluation of a new thermal insulation material from rice straw using high frequency hot-pressing. Energy Build. 2015, 87, 116-122. [CrossRef]

19. Hurtado, P.L.; Rouilly, A.; Vandenbossche, V.; Raynaud, C. A review on the properties of cellulose fibre insulation. Build. Environ. 2016, 96, 170-177. [CrossRef]

20. Madurwar, M.V.; Ralegaonkar, R.V.; Mandavgane, S.A. Application of agro-waste for sustainable construction materials: A review. Constr. Build. Mater. 2013, 38, 872-878. [CrossRef]

21. Ingrao, C.; Giudice, A.L.; Bacenetti, J.; Tricase, C.; Dotelli, G.; Fiala, M.; Siracusa, V.; Mbohwa, C. Energy and environmental assessment of industrial hemp for building applications: A review. Renew. Sustain. Energy Rev. 2015, 51, 29-42. [CrossRef]

22. Kymäläinen, H.-R.; Sjöberg, A.-M. Flax and hemp fibres as raw materials for thermal insulations. Build. Environ. 2008, 43, 1261-1269. [CrossRef]

23. Guzmán, R.E.; Gómez, S.; Amelines, O.; Aparicio, G.M. Superficial modification by alkalization of cellulose Fibres obtained from Fique leaf. In Proceedings of the IOP Conference Series: Materials Science and Engineering, Bristol, UK, 9-13 July 2018; Volume 437, p. 012015. [CrossRef]

24. An, L.; Wang, J.; Petit, D.; Armstrong, J.N.; Li, C.; Hu, Y.; Huang, Y.; Shao, Z.; Ren, S. A scalable crosslinked fiberglass-aerogel thermal insulation composite. Appl. Mater. Today 2020, 21, 100843. [CrossRef]

25. Dou, L.; Zhang, X.; Cheng, X.; Ma, Z.; Wang, X.; Si, Y.; Yu, J.; Ding, B. Hierarchical Cellular Structured Ceramic Nanofibrous Aerogels with Temperature-Invariant Superelasticity for Thermal Insulation. ACS Appl. Mater. Interfaces 2019, 11, 29056-29064. [CrossRef]

26. Vergara, M.C.A.; Gómez, M.P.C.; Restrepo, M.C.R.; Henao, J.M.; Soto, M.A.P.; Rojo, P.F.G.; Herazo, C.I.C.; Gallego, R.Z. Novel Biobased Textile Fiber from Colombian Agro-Industrial Waste Fiber. Molecules 2018, 23, 2640. [CrossRef]

27. Monteiro, S.; De Assis, F.S.; Ferreira, C.L.; Simonassi, N.T.; Weber, R.P.; Oliveira, M.S.; Colorado, H.A.; Pereira, A.C. Fique Fabric: A Promising Reinforcement for Polymer Composites. Polymers 2018, 10, 246. [CrossRef]

28. Fokaides, P.; Apanaviciene, R.; Černeckiene, J.; Jurelionis, A.; Klumbyte, E.; Kriauciunaite-Neklejonoviene, V.; Pupeikis, D.; Rekus, D.; Sadauskiene, J.; Seduikyte, L.; et al. Research Challenges and Advancements in the Field of Sustainable Energy Technologies in the Built Environment. Sustainability 2020, 12, 8417. [CrossRef]

29. Mansor, M.R.; Salit, M.S.; Zainudin, E.S.; Aziz, N.A.; Ariff, H. Life Cycle Assessment of Natural Fiber Polymer Composites. In Agricultural Biomass Based Potential Materials; Springer: Berlin/Heidelberg, Germany, 2015; pp. 121-141.

30. Cabeza, L.F.; Rincón, L.; Vilariño, V.; Pérez, G.; Castell, A. Life cycle assessment (LCA) and life cycle energy analysis (LCEA) of buildings and the building sector: A review. Renew. Sustain. Energy Rev. 2014, 29, 394-416. [CrossRef]

31. Muñoz, D.M.; Cifuentes, G.C. El fique como aislante térmico. Biotecnol. Sect. Agropecu. Agroind. 2007, 5, 9-16.

32. Onésippe, C.; Toro, F.; Bilba, K.; Delvasto, S.; Arsène, M.-A. Influence of Fibers Weight Fraction and Nature of Fibers on Thermal and Mechanical Properties of Vegetable Fibers/Cement Composites. In Proceedings of the 11th Conference on Durability of Building Materials and Components (11DBMC), Istanbul, Turkey, 11-14 May 2008. Available online: https:/ /hal.univ-antilles.fr/ hal-01693195/document (accessed on 18 June 2018.).

33. Monsalve, L.V.; Bolañoz, I.H.; Lopez, P.F.; Toro, E.F. Teja tipo sándwich de cemento basados en subproductos industriales para el mejoramiento de la comodidad térmica. Rev. Colomb. Mater. 2014, 5, 332-337. 
34. Navacerrada, M.A.; Diaz, C.; Pedrero, A.; Fernández-Morales, P.; Navarro, G.; Cardona, O. Caracterización AcúStica de Muestras de Fique Tejido y no Tejido. Available online: http:/ / www.sea-acustica.es/fileadmin/publicaciones/MAT-0_002.pdf (accessed on 12 May 2021).

35. Navacerrada, M.A.; Díaz, C.; Fernández, P. Characterization of a Material Based on Short Natural Fique Fibers. BioResources 2014, 9, 3480-3496. [CrossRef]

36. Proaño, E.; Bonilla, O.; Aldas, M. Desarrollo de un Material Compuesto de Matriz de Poliuretano Rígido Reforzado con Fibra de Raquis de Palma Africana. Rev. Politécnica 2015, 36, 89.

37. Navacerrada, M.A.; Díaz, C.; Pedrero, A.; Isaza, M.; Fernández, P.; Álvarez-Lopez, C.; Restrepo-Osorio, A. Caracterización Acústica y Térmica de no Tejidos Basados en Fibras Naturales; European Acoustics Association: Porto, Portugal, 2016.

38. Gutiérrez Vera, C.K. Estudio del Rendimiento Acústico y Térmico de la Fibra de Cabuya Como Panel para Revestimiento de Paredes; Universidad Laica Vicente Rocafuente: Guayaquil, Ecuador, 2017. Available online: http://repositorio.ulvr.edu.ec/handle/4400 0/2077 (accessed on 18 June 2018).

39. Sánchez, G.F.G.; Lopez, R.E.G.; Restrepo-Osorio, A.; Arroyo, E.H. Fique as thermal insulation morphologic and thermal characterization of fique fibers. Cogent Eng. 2019, 6, 1579427. [CrossRef]

40. Gomez, T.S.; Navacerrada, M.; Díaz, C.; Fernández-Morales, P. Fique fibres as a sustainable material for thermoacoustic conditioning. Appl. Acoust. 2020, 164, 107240. [CrossRef]

41. Hadded, A.; Benltoufa, S.; Fayala, F.; Jemni, A. Thermo physical characterisation of recycled textile materials used for building insulating. J. Build. Eng. 2016, 5, 34-40. [CrossRef]

42. ASTM C177-13 Standard Test Method for Steady-State Heat Flux Measurements and Thermal Transmission Properties by Means of the Guarded-Hot-Plate Apparatus. Available online: https://www.astm.org/DATABASE.CART/HISTORICAL/C177-13.htm (accessed on 16 May 2021).

43. Sher, F.; Iqbal, S.Z.; Liu, H.; Imran, M.; Snape, C.E. Thermal and kinetic analysis of diverse biomass fuels under different reaction environment: A way forward to renewable energy sources. Energy Convers. Manag. 2020, 203, 112266. [CrossRef]

44. Slopiecka, K.; Bartocci, P.; Fantozzi, F. Thermogravimetric analysis and kinetic study of poplar wood pyrolysis. Appl. Energy 2012, 97, 491-497. [CrossRef]

45. Jones, J.; Saddawi, A.; Dooley, B.; Mitchell, E.; Werner, J.; Waldron, D.; Weatherstone, S.; Williams, A. Low temperature ignition of biomass. Fuel Process. Technol. 2015, 134, 372-377. [CrossRef]

46. Coats, A.W.; Redfern, J.P. Kinetic Parameters from Thermogravimetric Data. Nat. Cell Biol. 1964, 201, 68-69. [CrossRef]

47. Álvarez, A.; Pizarro, C.; García, R.; Bueno, J.; Lavín, A. Determination of kinetic parameters for biomass combustion. Bioresour. Technol. 2016, 216, 36-43. [CrossRef]

48. Rueda-Ordóñez, Y.J.; Tannous, K. Isoconversional kinetic study of the thermal decomposition of sugarcane straw for thermal conversion processes. Bioresour. Technol. 2015, 196, 136-144. [CrossRef]

49. Vyazovkin, S.; Burnham, A.K.; Criado, J.M.; Perez-Maqueda, L.A.; Popescu, C.; Sbirrazzuoli, N. ICTAC Kinetics Committee recommendations for performing kinetic computations on thermal analysis data. Thermochim. Acta 2005, 520, 1-19. [CrossRef]

50. Perez-Maqueda, L.A.; Criado, J.M. The Accuracy of Senum and Yang's Approximations to the Arrhenius Integral. J. Therm. Anal. Calorim. 2000, 60, 909-915. [CrossRef]

51. Órfão, J.; Antunes, F.; Figueiredo, J. Pyrolysis kinetics of lignocellulosic materials—Three independent reactions model. Fuel 1999, 78, 349-358. [CrossRef]

52. Rueda-Ordoñez, Y.J. Thermal Decomposition Analysis of Sugarcane Straw in Inert and Oxidative Atmospheres through Thermoanalytical Methods. Ph.D. Thesis, University of Campinas, Campinas, Brazil, 2016. Available online: http://repositorio.unicamp. br/bitstream/REPOSIP/320795/1/RuedaOrdonez_YesidJavier_D.pdf (accessed on 2 September 2019).

53. Du, Z.; Sarofim, A.F.; Longwell, J.P. Activation energy distribution in temperature-programmed desorption: Modeling and application to the soot oxygen system. Energy Fuels 1990, 4, 296-302. [CrossRef] 